\title{
Chemically Thinning Blue Grama Range For Increased Forage and Seed Production
}

\author{
WILLIAM J. MCGINNIES
}

\section{Abstract}

Forage and seed production of blue grama rangeland can be increased by chemically thinning the native grass stand. Thinning of native blue grama range was accomplished by spraying strips 30 $\mathrm{cm}$ wide with glyphosate [N-(phosphonomethyl) glycine] and leaving alternating $15 \mathrm{~cm}$ wide strips of undisturbed vegetation. This reduced the stand to one-third of its original ground cover. Forage production was increased an average of $37 \%$ over the untreated pastures during a 7-year period. Plants in the thinned area were taller and had a more upright growth form which made the herbage more readily available to livestock. When plants were grazed during the winter, $67 \%$ more animal days of grazing were obtained from the thinned pastures than from the untreated pastures. For the 5 years when seed was harvested, production of clean seed averaged $5.6 \mathrm{~kg} / \mathrm{ha}$ on the untreated pastures and $13.0 \mathrm{~kg} / \mathrm{ha}$ on the thinned pastures.

In northern Wyoming, Rauzi (1980) reported that spraying strips of native range $36 \mathrm{~cm}$ wide with a heavy rate of atrazine [2-chloro-4-ethylamino-6-isopropyl amino-1,3,5-triazine] and leaving alternating bands of undisturbed vegetation $20 \mathrm{~cm}$ wide increased blue grama (Bouteloua gracilis) forage production. Production of blue grama during the first 5 years following treatment averaged $168 \%$ more than the untreated pastures and in the eleventh year was still $43 \%$ more.

In a study that evaluated the effects of growing space on individual plants of blue grama, as space per plant increased, the height of seed stalks, number of seed stalks per plant, and weight per plant increased (McGinnies 1971). Those plants with the most growing space had a more upright growth form than those with less growing space. When growing space was reduced to only $81 \mathrm{~cm}^{2}$ per plant, there was no mortality even in drought years, which indicated that blue grama can persist when severely crowded.

It was assumed that if a dense stand of native blue grama range could be thinned so that the remaining plants had more growing space and thus more water available, it might be possible to increase plant height and seed yield. Increasing plant height would make the forage more readily available to grazing livestock. Taller stems would also make seed easier to harvest with a combine.

In a preliminary small-plot study (unpublished) native blue

\footnotetext{
Author is range scientist, U.S. Department of Agriculture, Agricultural Research Service, Crops Research Laboratory, Colorado State University, Fort Collins 80523 The article is a cooperative investigation of USDA, ARS, Fort Collins, Colo., and the Colorado Agricultural Experiment Station, Fort Collins. Published with the approval of the Director of the Colorado Agr. Exp. Sta. as Scientific Series No. 2878

Manuscript accepted January 3, 1984.
}

grama range was thinned by chemically killing strips 15,30 , or 45 $\mathrm{cm}$ wide while leaving strips of living grass $15 \mathrm{~cm}$ wide between the killed strips. The treatment containing the $30-\mathrm{cm}$ killed strip appeared to produce more blue grama forage than the $15-\mathrm{cm}$ or $45-\mathrm{cm}$ treatments or the undisturbed range. Nitrogen fertilizer increased annual forbs but did not affect the yield of blue grama. Controlling annual forbs with a pre-emergence spray of atrazine in the year following thinning appeared to increase the effectiveness of the strip-sprayed treatment.

This study was initiated to evaluate the effects of chemically thinning blue grama range on forage and seed production. Increased carrying capacity would result from increasing forage yield and plant height to produce a more upright growth form which would make the herbage more readily available to livestock. McGinnies (1978) previously reported results from the first 2 years of this study.

\section{Methods}

In 1975, six 3.65-ha pastures were established on native blue grama range at the Central Plains Experimental Range $20 \mathrm{~km}$ north of Nunn in northcentral Colorado. The native shortgrass vegetation was predominately grasses and blue grama comprised approximately $90 \%$ of the grass and grass-like component of the vegetation. Associated grass and sedge species included threadleaf sedge (Carex filifolia), sand dropseed (Sporobolus cryptandrus), and bottlebrush squirreltail (Sitanion hystrix). Elevation was 1,650 $\mathrm{m}$ and average annual precipitation was $31 \mathrm{~cm}$ with $66 \%$ falling May through August. Soil was an Ascalon fine sandy loam (Aridic Argiustoll). The area had been moderately grazed since 1939.

During July 1975, vegetation in 3 of the 6 pastures was thinned by killing the plants in strips $30 \mathrm{~cm}$ wide by spraying glyphosate at a rate of $4.5 \mathrm{~kg} /$ ha in 280 liter/ha of water onto the strips. Alternating strips of unsprayed native vegetation $15 \mathrm{~cm}$ wide were left between the sprayed strips (Fig. 1). The final configuration consisted of strips of undisturbed native vegetation $15 \mathrm{~cm}$ wide separated by strips of killed vegetation $30 \mathrm{~cm}$ wide. The spray rate of 4.5 $\mathrm{kg} / \mathrm{ha}$ is the per ha rate for the treated strips. Because the sprayed strips occupy only $2 / 3$ of the surface area treated, the overall rate was $3.0 \mathrm{~kg}$ glyphosate per treated hectare. The 3 check treatment pastures received no spray treatment.

In early April, 1976, before any growth started, the thinned pastures were sprayed with atrazine at a rate of $1.1 \mathrm{~kg} /$ ha to control annual forbs. Because annual forbs were abundant in 1977, 1981, 


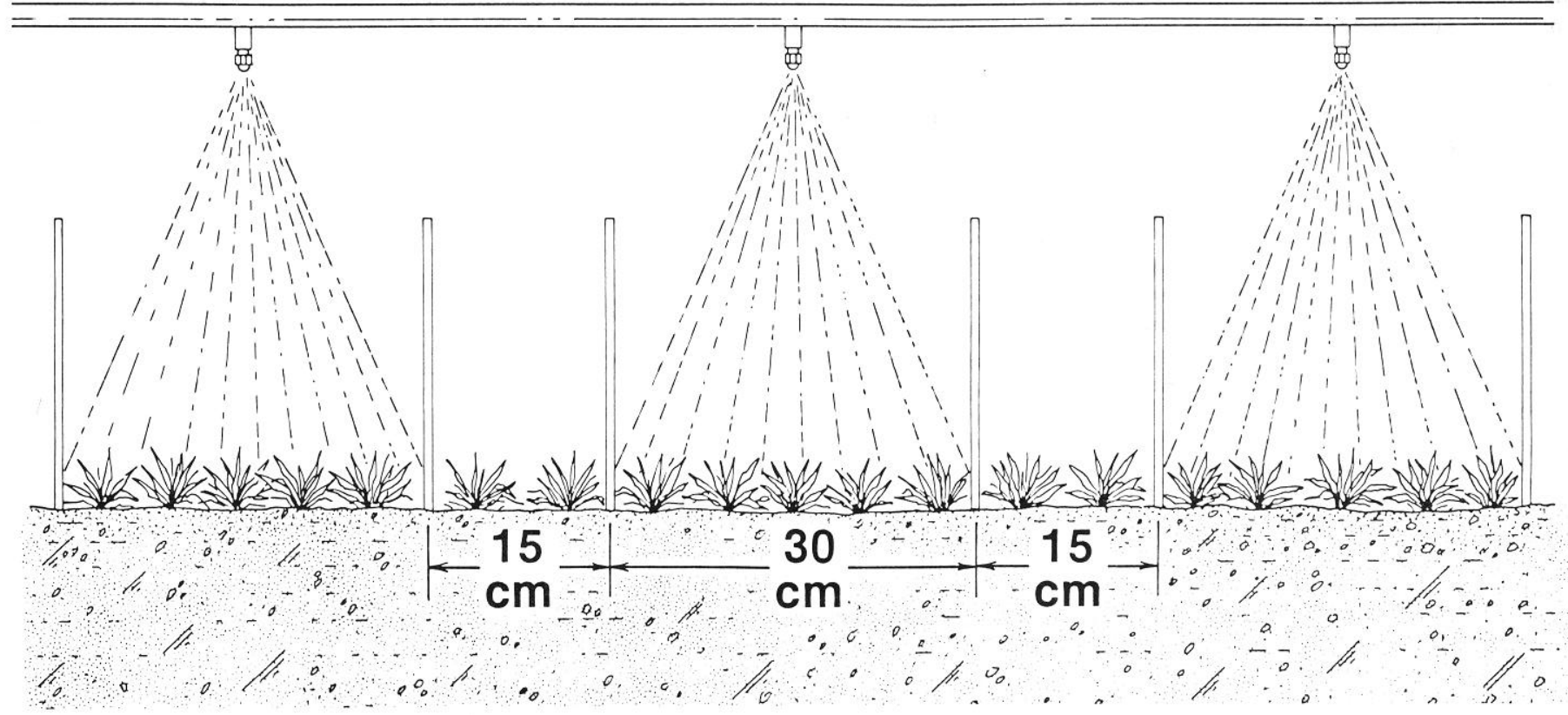

Fig. 1. Method of applying strip-spray thinning treatment. Metal shields confine spray to 30-cm wide killed strip while protecting 15 -cm wide unsprayed native vegetation.

and 1982 on the thinned pastures, they were broadcast sprayed with 2,4-D [(2,4-dichlorophenoxy)acetic acid)] in June. Annual forbs were never abundant enough to be considered a problem on the untreated pastures, and so were not sprayed with atrazine or 2,4-D.

Herbage yields were estimated on fifty $0.21-\mathrm{m}^{2}\left(2.25 \mathrm{ft}^{2}\right)$ plots in each pasture at the end of each growing season. Every fifth plot was both estimated and clipped, and the herbage sample was ovendried in order to adjust herbage estimates to an oven-dry basis.

Seed yield was measured by clipping the seed heads on twentyfive $0.21-\mathrm{m}^{2}$ plots in each pasture. Seed heads (spikes) were counted, and the seed threshed and weighed to obtain an estimate of clean seed per ha.

The pastures were grazed during January, February or March with yearling heifers at a ratio of 5 heifers for thinned pastures to 3 heifers for untreated check pastures. Pastures were usually grazed until approximately $325 \mathrm{~kg} /$ ha of herbage remained. In years when less than $325 \mathrm{~kg} /$ ha were produced, heifers were allowed to graze until it appeared that they could not easily obtain enough to eat.

To determine how much the blue grama had invaded the sprayed strips, 150 measurements of the width of the bare strips between the strips of native vegetation were made in the late fall of 1982 .

There were 3 replications in a randomized complete block design. Differences in treatment means were evaluated by analysis of variance. Other relationships were evaluated by linear correlation.

\section{Results and Discussion}

The average kill of blue grama in the sprayed strips was estimated to be 80 to $90 \%$, but ranged from about 75 to $100 \%$. Lack of rainfall in the period preceding spraying resulted in unfavorable growing conditions and reduced plant vigor, which resulted in the blue grama kill of less than $100 \%$. Early growing species such as threadleaf sedge and bottlebrush squirreltail had largely completed their growth for the season and were little affected by the glyphosate.

The 1976 application of atrazine almost completely eliminated the annual forbs in the strip sprayed pastures. Those few annual forbs that escaped the spray, mostly Russianthistle (Salsola kali), were very large (Fig. 2). Because of the competition from the dense stand of blue grama, few annual forbs grew on the untreated pastures and those that did grow were generally small. Hyder et al. (1976) and Houston (1977) reported that atrazine had little or no effect on blue grama. In this study, the atrazine was applied in early

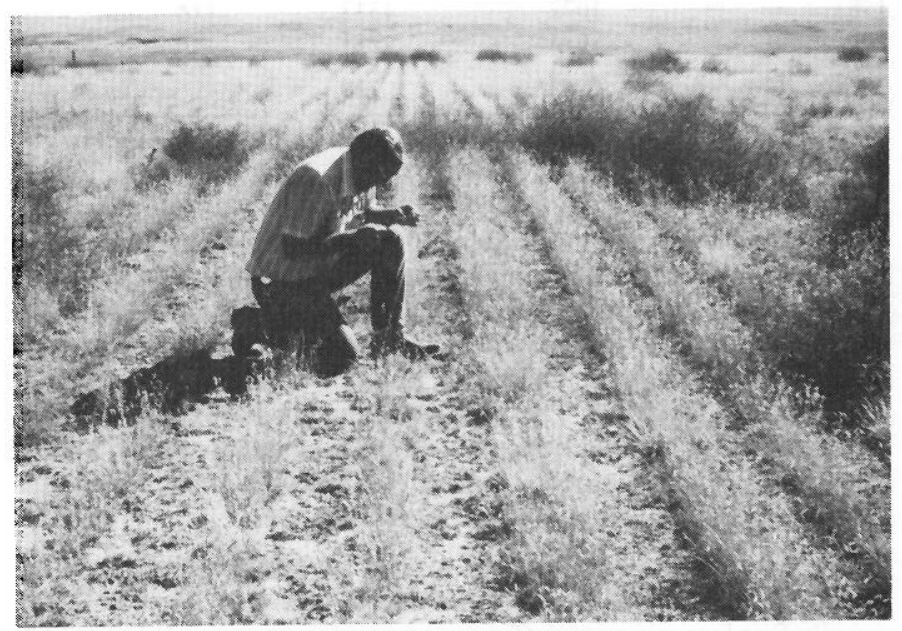

Fig. 2. Strip spray treatment in late summer, 1976, showing upright growth form and abundant seedheads. Killed plants in sprayed strips remain and protect soil surface from erosion. Large dark weeds in picture are individual plants of Russian thistle that escaped pre-emergence atrazine spray.

April, which is well before blue grama starts to green up. There were no observable effects of this early atrazine application on the blue grama.

The 2,4-D was much less effective than atrazine for controlling annual forb growth. The 2,4-D was not applied until it was felt that the annual forbs presented a problem, and by then the annual forbs were under a moisture stress which reduced the effectiveness of the 2,4-D. In spite of this, it was felt that the 2,4-D was effective in reducing competition from annual forbs during July and August. Annual forbs were never abundant in the untreated pastures and were not considered to be a problem.

The blue grama plants were much taller (both leaves and stems) and appeared more vigorous on the strip-sprayed pastures than in 
the untreated pastures. During periods when the soil dried out during the summer, the plants in the strip sprayed pastures usually remained green and showed no signs of stress, but the plants in the check pastures appeared to be dry and severely stressed. Thus, moisture was available to the plants in the strip-sprayed pastures for longer periods than for the plants in the check pastures.

During 1978, the third of 3 consecutive dry years, considerable die-off of blue grama occurred in the untreated pastures. Most of the die-off resulted from parts of individual grass clumps dying while the remainder survived. In the strip-sprayed pastures, no die-off was observed, and plants stayed green most of the summer. Reducing the number of plants by two-thirds created a situation where those plants that remained apparently had adequate soil moisture to stay green during a severe drought, but in the untreated pastures where the grass had not been thinned the soil moisture was inadequate to support the much higher plant density.

Strip-sprayed pastures produced significantly more herbage than the untreated pastures in all years. During the 7 years of this study, herbage production on the thinned pastures averaged $37 \%$ greater than in the check pastures (Table 1), and ranged from a low

Table 1. Yield (kg/ha) by years for thinned and untreated pastures, 1976-1982.

\begin{tabular}{lccc}
\hline Year & $\begin{array}{c}\text { Untreated } \\
\text { pastures }\end{array}$ & $\begin{array}{c}\text { Strip } \\
\text { spray }\end{array}$ & $\begin{array}{l}\text { Significance of } \\
\text { differences }\end{array}$ \\
\hline 1976 & 306 & 445 & $* * * 1$ \\
1977 & 297 & 333 & $* * *$ \\
1978 & 121 & 249 & $* * *$ \\
1979 & 633 & 897 & $* * *$ \\
1980 & 900 & 1059 & $* * *$ \\
1981 & 1072 & 1333 & $* * *$ \\
1982 & 623 & 711 & $* *$ \\
Mean & 565 & 718 & \\
\hline
\end{tabular}

$*=p<.05$

$* *=p<.01$.

of $12 \%$ greater in 1977 to a high of $105 \%$ in 1978 . In terms of actual yield, the increase due to thinning ranged from a low of $36 \mathrm{~kg} / \mathrm{ha}$ in 1977 to more than $260 \mathrm{~kg} / \mathrm{ha}$ in both 1979 and 1981 , and averaged $153 \mathrm{~kg} /$ ha for the 7-year period. There were no significant correlations between herbage yield and annual, seasonal, or monthly recorded precipitation. The poor relationship between precipitation and forage production may, in part, result from the highly localized nature of storms during the growing season and the nearest rain gauge being $2 \mathrm{~km}$ from the pastures.

Duin treatments were grazed in mia- to late-winter (Janua y, February, or March). It was found that the number of cattle used, usually 5 or less, was not sufficient to provide meaningful carrying capacity data because animal response could not be measured with a suitable level of statistical probability. In spite of this problem, in most years the pastures were grazed at a ratio of 5 animals on the strip-sprayed pastures to 3 animals on the untreated check pastures, or $67 \%$ more animal-days use on the strip-sprayed pastures. Animals were moved when it appeared that they had consumed the readily available herbage. Thinning produced a more upright growth form which made a higher proportion of the herbage available for grazing. This relationship produced an apparent increase in carrying capacity that was greater than expected from the increase in herbage weight alone. The effect of thinning on carrying capacity will be evaluated more thoroughly in a future study where pastures will be large enough to permit a satisfactory statistical analysis of animal production data.

Cleaı seed yields of blue grama in this section of the Great Plains are low even in favorable years. Clean seed yields averaged 5.6 $\mathrm{kg} / \mathrm{ha}$ in the check treatment and $13.0 \mathrm{~kg} / \mathrm{ha}$ in the thinned pastures for the 5 years that seed production was sampled (Table 2). In
Table 2. Yield of clean seed in $\mathrm{kg} / \mathrm{ha}$ and number of seed $s$ talks $/ \mathrm{m}^{2}$ for thinned and untreated pastures.

\begin{tabular}{lcccc}
\hline \hline Item & Year & $\begin{array}{c}\text { Untreated } \\
\text { pastures }\end{array}$ & Thinned & $\begin{array}{c}\text { Significance of } \\
\text { differences }\end{array}$ \\
\hline Seed yield & 1976 & 4.0 & 24.2 & $* * * 1$ \\
& 1977 & 0.9 & 5.4 & $* * *$ \\
& $1980^{2}$ & 4.9 & 20.4 & $* * *$ \\
& 1981 & 5.8 & 7.7 & NS \\
& 1982 & 4.5 & 7.1 & $*$ \\
Seed stalks & 1976 & 44 & 211 & $* * *$ \\
& 1977 & 16 & 73 & $* * *$ \\
& 1978 & 56 & 84 & $*$ \\
& 1979 & 140 & 208 & $* * *$ \\
& 1980 & 187 & 265 & $* *$ \\
& 1981 & 126 & 170 & $* * *$ \\
\hline
\end{tabular}

$\begin{aligned} & 1 *=p<.05 \\ & * *=p<.01 \\ & * * *=p<.005 \\ & \text { 2Seed not harvested in } 1978 \text { or } 1979 .\end{aligned}$

1981 and 1982 there was considerable mid- to late-summer precipitation, and more than one crop of seed heads was produced. At the time the seed samples were collected, some seedheads were still green while others had already shattered. In 1976 and 1980, the seedheads all matured at approximately the same time.

Number of seed stalks per $\mathrm{m}^{2}$ averaged 95 in the untreated pastures and 165 in the strip-sprayed areas for the 7-year period. The number of seed stalks was correlated with herbage yield $(r=.55$ for thinned treatment and $r=.78$ for the check treatment, both $p<$ $.01)$. The number of seed stalks also was related to seed yields $(r=$ .81 for the thinned treatment, $p<.01$; and $r=.51$ for the untreated check pastures, $p<.05$ ). There was poor correlation between number of seed stalks and total, seasonal, or monthly recorded precipitation.

In 1982, the widths of the killed strips were measured. Blue grama reinvaded the bare areas in varying degrees; the amount of reinvasion appears to be related to characteristics of individual patches of blue grama. In some patches, the sprayed strip was completely revegetated, but in adjacent patches there had been almost no reinvasion. Although the rate of reinvasion appeared to be related to genetic differences among plants, it may have been influenced by minor soil or micro-relief differences (differences among plants are currently being investigated). The width of the killed strips, which was $30 \mathrm{~cm}$ in 1975 , averaged $16 \mathrm{~cm}$ in 1982 . When the strips become so narrow that they no longer increase herbage yield or cause a more upright growth form, re-treatment of the area will need to be considered.

Although there was some slight hummocking of the strips of unsprayed vegetation, there was no evidence of accelerated erosion from the sprayed strips. The plants killed by glyphosate remained to protect the site from erosion; dead root crowns were still visible in the sprayed strips in 1982 . Spraying probably resulted in less soil erosion than would be expected with a mechanical thinning of the stand because spraying did not disturb the soil. Spraying on the contour should reduce any tendency for water to channel down the bare sprayed rows.

\section{Conclusions}

Herbage production and carrying capacity of blue grama rangeland can be increased by chemically thinning dense grass stands such as those in this study. Thinning results in fewer plants competing for available supplies of soil moisture and plant nutrients, and this in turn means that these fewer plants growing under more favorable moisture conditions will be able to grow and reproduce. This is in contrast to the many plants in the undisturbed areas where the individual plants must use most of the available water, 
particularly in dry years, just to survive, and there is little water left over for growth. The more upright growth form and taller plants observed in the strip-sprayed pastures agrees with previous observations made on individual plants where growing space per plant was controlled to simulate the effects of plant spacing (McGinnies 1971). This, again, may represent a response to more water being made available to the individual plants.

Determination of the economic feasibility of thinning must await more extensive grazing trials where any increase in carrying capacity can be measured. Other economic considerations will include the cost of treatment and the rate of reinvasion which, in turn, will determine how soon retreatment will be needed. Improved spraying techniques are now being developed which will reduce the amount of herbicide required and increase the percentage kill in the sprayed strips. Chemical treatment is to be preferred over lower- cost mechanical renovation techniques because of reduced erosion potential.

\section{Literature Cited}

Houston, W.R. 1977. Species susceptibility to atrazine herbicide on shortgrass range. J. Range Manage. 30:50-52.

Hyder, D.N., W.R. Houston, and J.B. Burwell. 1976. Drought resistance of blue grama as affected by atrazine and $\mathrm{N}$ fertilizer. J. Range Manage. 29:214-216.

McGinnies, W.J. 1971. Effects of controlled plant spacing on growth and mortality of three range grasses. Agron. J. 63:868-870.

McGinnies, W.J. 1978. Thinning of blue grama range for increased seed and forage production. p. 645-646. In: D.N. Hyder (Ed.) Proc. 1st Int. Rangeland Congr., Soc. Range Manage. Denver, Colo.

Rauzi, F. 1980. Herbage yields from a clayey range site 10 and 11 years after severe renovation. J. Range Manage. 33:379-381. 